Volume VII , Nomor 1, Juni 2021 : Hal 29-33

Jurnal Utile

https://jurnal.ummi.ac.id/index.php/JUT

\title{
PENGARUH SENAM BUGAR MUHAMMADIYAH TERHADAP KEBUGARAN JASMANI PADA SISWA USIA 16-19 TAHUN DI SEKOLAH SMK NURUL FAJAR KABUPATEN BOGOR TAHUN PELAJARAN 2019/2020
}

\author{
Riska Marselianda \\ Universitas Muhammadiyah Sukabumi \\ Jl. R. Syamsudin, S.H. No. 50, Kota Sukabumi/ Sukabumi, Jawa Barat, Indonesia \\ Rmarselianda@gmail.com
}

\begin{abstract}
Abstrak: Dalam penelitian ini, penulis memiliki tujuan untuk mengetahui pengaruh kebugaran jasmani melalui senam bugar muhammadiyah terhadap siswa keperawatan SMK Nurul Fajar Kabupaten Bogor Tahun Pelajaran 2019/2020 pada bentuk penelitian kuantitatif dengan metode eksperimen dan pengambilan sampel dilakukan dengan menggunakan teknik purposive sampling yang berjumlah 4 orang dari 22 populasi. Penelitian ini dilakukan dengan cara mengukur kebugaran jasmani melalui TKJI sebelum dan sesudah diberikan treatment senam bugar muhammadiyah. Metode penelitian ini mengunakan uji normalitas dengan hasil pretest diketaui asymp.sig $=0.995$ dengan information normal dan hasil posttest diketahui asymp.sig $=0.846$ dan information, normal, dari hasil uji $\mathrm{T}$ dengan penghitungan diperoleh 0.495 . Hasil tersebut lebih besar dari 0.05 , hasil ini memperoleh hipotesis Ha ditolak, yang artinya Ho = tidak ada pengaruh yang signifikan dari latihan senam bugar muhammadiyah., uji homogenitas dengan menggunakan SPSS 21, hasil penelitian dengan menggunakan latihan senam bugar muhammmadiyah mendapatkan pengaruh yang dimana dengan kategori "sedang" akan tetapi tidak signifikan pada siswa kelas XII keperawatan SMK Nurul Fajar Kabupaten Bogor.
\end{abstract}

Kata Kunci: : Kebugaran Jasmani, TKJI, Senam Bugar Muhammaadiyah, SMK

Abstract: This research aimed to determine the effect of physical fitness though Muhammadiyah gymnastics on nursing student of SMK Nurul Fajar, Bogor district, 2019/2020 academic year in the form of quantitative research with experimental methods and sampling was carried out using purposive sampling technique, amounting, to 4 people from 22 populations. This research was conducted by measuring physical fitness through TKJI before and after being given Muhammadiyah fitness treatment. This research method uses the normality test with pretest results known as asymp.sig $=0.995$ with normal information and posttest results known asymp.sig $=0.846$ and information, normal, from the T test results with the calculation obtained 0.495 . This result is greater than 0.05, this result indicates that the hypothesis Ha is rejected, which means that Ho = there is no significant effect of Muhammadiyah fitness training Homogeneity test using SPSS 21, the results of the study using muhammmadiyah fitness exercises have an effect which is in the "moderate" category but not significant in class XII nursing students of SMK Nurul Fajar, Bogor Regency.

Keywords: Physical Fitness, TKJI, Gymnastics Fitness Muhammaadiyah, SMK

History :

Submit tgl 05 Desember 2020, review 11 Desember 2020, Accepted 11 Desember 2020 


\section{PENDAHULUAN}

Kegiatan Olahraga sangatlah perlu bagi kebugaran jasmani kita yang dimana membuat tubuh kita menjadi sehat dan bugar akan tetapi anak muda dii masa remaja sangatlah jarang untuk melakukan olahraga dengan 3 kali dalam seminggu. Pembelajaran pendidiakan jasmani merupakan media untuk mendorong perkembangan keterampilan motorik, kemampuan fisik, pengetahuan, penalaran, penghayatan nilai (sikap-mentalemosional-spiritualsosial), dan pembiasaan pola hidup sehat yang bermuara untuk merangsang pertumbuhan serta perkembangan yang seimbang. Maka dampak dari Kebugaran jasmani dan Kesehatan yaitu aspek yang sangat penting untuk diperhatikan oleh semua orang apalagi untuk para peserta didik yang sudah merasakan dampak kemajuan teknologi ini yang dimana tingkat kebugaraanya kurang.

Oleh karena itu Pendidikan Jasmani merupakan media untuk mendorong perkembangan keterampilan motorik, kemampuan fisik, pengetahuan, penalaran, penghayatan nilai (sikap-mental-emosionalspiritualsosial), dan pembiasaan pola hidup sehat yang bermuara untuk merangsang pertumbuhan serta perkembangan yang seimbang. Maka dampak dari Kebugaran jasmani dan Kesehatan yaitu aspek yang sangat penting untuk diperhatikan oleh semua orang apalagi untuk para peserta didik yang sudah merasakan dampak kemajuan teknologi ini yang dimana tingkat kebugaraanya kurang.

Melakukan aktifitas kebugaran dalam satu kali dalam seminggu sangatlah kurang efektif maka dari itu sebaiknya untuk meningkatkan kebugaran jasmani dilakukan kegiatan olahraga minimal tiga hari dalam, yang dimana dengan senam bugar muhammadiyah dapat membantu siswa SMK Nurul Fajar Kabupaten Bogor memiliki kebugaran jasmani yang baik dan dapat melakukan aktifitas latihan fisik tiga kali dalam seminggu dengan menggunakan Senam Bugar Muhammadiyah dari Universitas Muhammadiyah Sukabumi yang diciptakan oleh Wening Nugraheni M.Pd dan Titis Nurina M.Or selaku dosen prodi Pendidikan Jasmani. video/televise pendidikan, video/televise instruksional, program slide suara, dan program CD interaktif.

Menurut Titis Nurina, Wening Nugraheni (2018: 175) Senam kebugaran merupakan salah satu jenis senam yang familiar di kalangan masyarakat karena diajarkan di sekolahsekolah. Bahkan di sekolah-sekolah Muhammadiyah juga diajarkan senam tersebut. Jadi senam bugar muhammadiyah adalah aktifitas fisik yang dimana gerakannya diirigi dengan musik atau irama dengan gerakan yang struktur. pengaruh-pengaruh psikologis terhadap siswa."

Secara umum dapat disimpulkan bahwa mendapatkan kebugaran jasmani tidaklah cukup dengan melakukan satu kali dalam seminggu. 


\section{METODOLOGI PENELITIAN}

Jenis penelitian yang digunakan dalam penelitian ini adalah Dalam melakukan sebuah penelitian harus menggunakan sebuah metode penelitian, menurut Sugiyono (2012: 2), "metode penelitian adalah cara ilmiah untuk mendapatkan data dengan tujuan dan kegunaan tertentu". dari pendapat ahli tersebut dapat disimpulkan bahwa metode penelitian adalah suatu cara yang sudah mempunyai susunan secara sistematis yang digunakan pada penelitian untuk mencari pemecahan terhadap suatu masalah.

Partisipan dalam penelitan ini yaitu siswa kelas XII keperawatan di SMK Nurul Fajar Kabupaten Bogor 2019/2020 yang berjumlah 4 siswa. Subjek penelitian ini dilaksanakan berdasarkan penemuan permasalahan yang ada di kelas XII dengan usia 16-19 tahun. Penelitian ini menggunakan pengambilan sampel dengan teknik purposive sampling adapun permasalahan pada penelitian ini yaitu mengenai kebugaran jasmani..

Penelitian ini menggunakan instrument TKJI ( Tes Kebugaran Jasmani Indonesia) untuk mengawali data penelitian. Menggunakan tes TKJI (Tes Kebugaran Jasmani Indonesia) untuk usia $16 \mathrm{~s} / \mathrm{d} 19$ tahun yang terdiri dari 5 test (Nurhasan,2013) yang terdiri dari : Lari cepat 60 meter untuk siswa dan siswi., Gantung tubuh dan gantung siku tekuk., Baring duduk., Loncat tegak., Lari jarak $1200 \mathrm{~m}$. Setelah selesai melakukan tes kebugaran jasmani Indonesia (TKJI) sesuai kategori yaitu usia 16 sampai 19 tahun kita harus menjumlahkan semua hasil nilai dari 5 test tersebut dan cocokan dengan jumlah nilai : 22 - 25 ( Baik sekali ), 18 - 21 ( Baik ), 14 17 ( Cukup ), $10-13$ (Kurang ), $05-09$ ( Kurang sekali ).

\section{HASIL PENELITIAN DAN PEMBAHASAN}

Penelitian dilakukan pada hari 30 Agustus 2020 sampai dengan 19 Oktober 2020. Populasi dan sampel dalam penelitian ini ialah siswa kelas Keperawatan SMK Nurul Fajar Kabupaten Bogor Tahun Pelajaran 2019/2020 berjumlah 4 siswa, dari 22 siswa di kelas keperawatan SMK Nurul Fajar Kabupaten BogorTujuan dalam penelitian ini untuk mengetahui dalam gerakan senam bugar muhammadiyah apakah dapat berpengaruh terhadap kebugaran jasmani pada siswa dengan umur 16-19 tahun. Setelah diberi treatment senam bugar muhammadiyah sampel mengalami kenaikan kebugaran namun tidak signifikan.

Hasil dari data tes awal dan tes akhir kebugaran jasmani yang menggunakan tes kebugaran jasmani Indonesia pada siswa kelas XII keperawatan SMK Nurul Fajar Kabupaten Bogor yang dapat diuraikan sebagai tabel berikut awal penelitian yang bertujuan untuk mengamati adakah pengaruh senam bugar jasmani yang berkaitan dengan kebuggaran jasmani. Berdasarkan hasil Pretest kebugaran jasmani melalui TKJI yang dilaksanakan pada tanggal 30 Agustus 2020. diketahui bahwa siswa yang memiliki kebugaran jasmani termasuk ukuran "sedang" yaitu memperoleh dengan jumlah nilai 15-16 hanya 2 orang dan 2 
orang dengan jumlah nilai 12-13 termasuk ukuran "kurang". Sementara itu, untuk memiliki kebugaran jasmani memberikan standar nilai batas minimal $14-17$ menurut norma tes kebugaran jasmani indonesia Dari paparan di atas berarti hanya 2 siswa yang sudah memenuhi standar kebugaran jasmani. Setelah melakukan treatment senam bugar muhammadiyah melakukan 12 kali pertemuan dengan program latihan yang sudah ditentukan dalam seminggu melakukan kegiatan senam ini dengan 3 kali dalam seminggu dan hasilnya memiliki pengaruh dalam treatment ini dengan 4 siswa memperoleh hasil "sedang". Dari hasil pretest di atas membuktikan bahwa proses kebugaran jasmani masih jauh dari harapan dan dari hasil posttest di atas memiliki proses pengaruh yang baik walau tidak signifikan.

Tabel 1 Hasil Analisis Data pretest dan posttest pada kebugaran jasmani

\begin{tabular}{|c|c|c|c|}
\hline $\begin{array}{c}\text { Tes } \\
\text { Kebugaran } \\
\text { Jasmani } \\
\text { Indonesia }\end{array}$ & N & $\begin{array}{c}\text { Rata- } \\
\text { rata }\end{array}$ & SD \\
\hline $\begin{array}{c}\text { Pretest } \\
\text { Kebugaran } \\
\text { Jasmani }\end{array}$ & 4 & 14.00 & 1.82 \\
\hline $\begin{array}{c}\text { Posttest } \\
\text { Kebugaran } \\
\text { Jasmani }\end{array}$ & 4 & 14.50 & 0.57 \\
\hline
\end{tabular}

Berdasarkan penjelasan pada tabel 1 dapat diketahui bahwa $\mathrm{N} 4$ dengan nilai dari pretest dan posttest kebugaran jasmanin $\mathrm{N} 4$, dengan pretest yang memiliki nilai rata-rata $14.00, \mathrm{SD}$ 1.82. dan posttest memiliki nilai rata-rata 0.50 ,
SD 0,57. Hasil dari penghitungan yang menggunakan metode pendekatan uji normalitas dengan hasil pretest diketaui asymp.sig $=0.995$ dengan information normal dan hasil posttest diketahui asymp.sig $=0.846$ dengan information normal. Yang dimana hasilnya normal. Dan dari hasil uji homogenitas yang bertujuan untuk mengetahui apakah populasi itu sama atau tidak. Dari tabel di atas dapat diketaui hasilnya dari F(Hitung) $=0.13$ dan $\mathrm{F}($ Tabel $)=0.5$. Hasil dari F(Hitung) lebih besar dari F(Tabel). Dapat disumpulkan bahwa data dari penelitian ini homogen atau sama.

Hasil dari penghitungan yang menggunakan metode pendekatan uji $\mathrm{T}$ hasil yang diperoleh adalah 0.495. Hasil tersebut lebih besar dari 0.05 , hasil ini memperoleh hipotesis Ha ditolak, yang artinya $\mathrm{Ho}=$ tidak ada pengaruh yang signifikan dari latihan senam bugar muhammadiyah. Kesimpulan

Berdasarkan hasil analisis data yang sudah diketahui dan dibahas maka dapat ditarik kesimpulan bahwa tidak ada pengaruh latihan senam bugar muhammadiyah terhadap kebugaran jasmani siswa kelas XII Keperawatan SMK Nurul Fajar Kabupaten Bogor dikarenakan berkurangnya sampel menjadi 4 orang dan melalui media video dikarenakan adanya wabah penyakit Covid 19 dan tidak 
memiliki instruktur yang sudah mempengaruhi hasil Fhitung dan variansi 1 lebih kecil dan lamanya latihan hanya 12 kali pertemuan. Penelitian ini tidak sepenuhnya tidak memiliki hasil tapi adanya manfaatnya bagi guru ataupun pelatih untuk menyusun program latihan yang sudah disusun secara, metodis, logis, terkonsep, sistematis dan terorganisir. Dalam penelitian ini dapat dilihat secara dalam pemberian program latihan tidak asal-asalan dimana harus memperhatikan jeda latihan dan itensitas latihan atau beban latihan yang diberikan dikarekanan sudah disetujui oleh para ahli dalam bidan ini dan pemberian program yang salah sangatlah berbahaya bagi peserta didik ataupun atlet.

\section{Daftar Pustaka}

Nurina Titis, Nugraheni Wening.2018. Senam Bugar Muhammadiyah" Untuk Meningkatkan Kebugaran Jasmani Warga Muhammadiyah. Asosiasi Program Pascasarjana Perguruan Tinggi Muhammadiyah Dan Aisyiah (Appptma). ISBN: 978-623-90018-1-0Permana, rahmat. juni 2016. Penguasaan rangkaian tes kebugaran jasmani Indonesia (tkji) melalui diskusi dan simulasi. Jurnal Refleksi Edukatika Vol. 6 No 2
Sugiyono. 2014. Metode Penelitian Pendidikan Pendekatan

Kuantitatif, Kualitatif, dan $R \& D$. bandung : Alfabeta

Zulheri Is. 1 Januari - Juni 2014 . Tingkat kebugaran jasmani siswa smp it nurul islah banda aceh. Mahasiswa $\quad$ S1 Prodi Pendidikan Jasmani, Kesehatan dan Rekreasi STKIP Bina Bangsa Getsempena Volume 1 Nomer ISSN $2355-0058$ 